\title{
ANALISIS EFISIENSI PENGGUNAAN LAMPU HEMAT ENERGI (LHE) DAN BALLAST ELEKTRONIK PADA LAMPU NEON
}

\author{
Sudirman Syam ${ }^{1}$, Sri Kurniati ${ }^{2}$, Jauhari Effendi ${ }^{3}$ \\ 1,2,Program Studi Teknik Elektro, Fakultas Sains dan Teknik Universitas Nusa Cendana, Kupang-NTT, Indonesia, \\ ${ }^{3}$ Program Pascasarjana Ilmu Lingkunngan Universitas Nusa Cendana, Kupang-NTT, Indonesia,

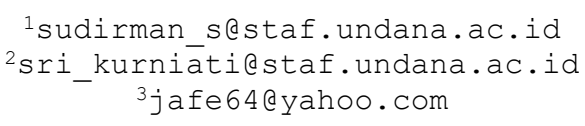

\begin{abstract}
Increased technological growth absorbs a lot of energy and is a very frightening periodic energy crisis incident. At present, there has been a change in the pattern of the use of ordinary lamps to save lamps from conventional ballasts to electronic ballasts and energy saving lamps (LHE). The purpose of this study is to analyze and evaluate electrical energy savings from the use of conventional ballasts to electronic ballasts. The results showed that, the use of energysaving lamps requires an initial cost that is more expensive than ordinary lamps, but in daily operations it becomes more economical so that energy savings are obtained between 20 $80 \%$. The existence of a replacement pattern from ordinary lamps to saving lamps will be able to help PLN to reduce reactive energy so that it will reduce energy losses that occur in the electricity network. In addition, the change of conventional ballast to electronic ballast will increase the electric power factor by $55.61 \%$.
\end{abstract}

Keywords-Energy Saving Lamps, Electronic Ballasts, Power Factors

Intisari-Peningkatan pertumbuhan teknologi menyerap banyak energi dan merupakan insiden krisis energi periodik yang sangat menakutkan. Saat ini, telah terjadi perubahan pola penggunaan lampu biasa untuk menghemat lampu dari ballast konvensional ke ballast elektronik dan lampu hemat energi (LHE). Tujuan penelitian ini adalah menganalisis dan mengevaluasi penghematan energi listrik dari penggunaan ballast konvensional menjadi ballast elektronik. Hasil penelitian menunjukkan bahwa, penggunaan lampu hemat energi memerlukan biaya awal yang lebih mahal dibandingkan dengan lampu biasa, tetapi dalam operasi sehari-hari menjadi lebih ekonomis sehingga diperoleh penghematan energi antara $20-80 \%$. Adanya pola penggantian dari lampu biasa menjadi lampu hemat akan dapat membantu PLN untuk mengurangi energi reaktif sehingga akan mengurangi rugi-rugi energi yang terjadi pada jaringan listrik. Sebagai tambahan, adanya perubahan penggantian ballast konvensional menjadi ballast elektronik akan dapat meningkatkan faktor daya listrik sebesar $55,61 \%$.

Kata Kunci-Lampu Hemat Energi, Ballast Elektronik, Faktor Daya

\section{PENDAHULUAN}

Peningkatan konsumsi energi merupakan sesuatu yang tidak bisa kita hindari seiring dengan peningkatan kesejahteraan masyarakat dan perkembangan jumlah penduduk. Sementara ketersediaan energi semakin berkurang karena eksploitasi yang terus menerus dan penemuan-penemuan sumber energi baru yang tidak sebanding dengan besarnya konsumsi energi itu sendiri. Sebagai contoh dapat dilihat dari konsumsi energi listrik di Indonesia pada tahun 1994 yang besarnya 51.478,38 GWH, pada tahun 1998 meningkat menjadi 77.903,37 GWH [1]. Akibatnya masalah energi akan menjadi masalah yang sangat peka di masa - masa yang akan datang. Oleh karena itu, ketersediaan energi ini sudah selayaknya menjadi perhatian seluruh masyarakat dunia.

Selama bertahun-tahun, berbagai keunggulan Ballast Elektronik (BE) telah diuraikan oleh para peneliti sebelumnya seiring dengan kemajuan di sektor elektronik daya seperti pengurangan biaya energi, baik di sektor rumah tangga maupun sektor industri [2]. Selain itu, kemampun efisiensinya juga lebih tinggi dibanding dengan lampu fluorescen yang disuplai pada frekuensi tinggi yang berdampak pada penghematan energi secara signifikan bila dibandingkan dengan lampu pijar [3-4]. Saat ini, telah diperoduksi lampu fluorescent dengan BE sebagai pengganti ballast konvensional (BK) atau ballast induktif yang mirip seperti lampu pijar dan dapat mengurangi konsumsi energi dengan faktor 4 atau 5 [5-6]. Lampu ini dikenal dengan Compact Fluorescent Lampu (CFL).

Inverter setengah jembatan biasanya digunakan pada pembuatan lampu hemat energi ini dengan biaya yang lebih murah dan ukuran lampu yang lebih simpel [7-11]. Kekuatan lampu ini biasanya di bawah $25 \mathrm{~W}$ dengan umur pemakaian rata-rata antara 8 - 15 kali dibanding dengan lampu pijar. CFL biasanya memiliki umur pemakaian antara 6.000 dan 15.000 jam, sedangkan lampu pijar biasanya diproduksi hanya memiliki masa pakai 750 jam atau 1.000 jam [12].

Dalam paper ini akan menganalisis perbandingan penggunaan energi lampu hemat energi dengan lampu ballast konvensional serta lampu pijar. Dengan demikian dapat diperoleh informasi penggunaan kedua lampu tersebut secara ekonomis. Dengan demikian, masyarakat dapat memahami keunggulan LHE dan tidak cenderung memilih lampu yang murah, namun kenyataannya tidak hemat energi, seperti lampu pijar dan lampu neon yang menggunakan BK. Selain itu, penggunaan lampu dengan ballast konvensional juga penyebab timbulnya harmonik pada jaringan listrik [13]. 


\section{LANDASAN TEORI}

\section{A. Sejarah Perlampuan}

Lampu pertama kali ditemukan oleh Thomas Alfa Edison pada tahun 1878 dalam bentuk lampu pijar. Ditinjau dari material maupun bentuk fisik dan teknologinya, lampu ini telah mengalami banyak perubahan dibandingkan pada awal penemuannya. Prinsip kerja dari lampu listrik berdasarkan dengan cara menghubung singkat arus listrik pada filamen carbon (C) sehingga terjadi arus hubung singkat yang mengakibatkan timbulnya panas. Akibatnya, adanya panas sehingga terjadi kenaikan suhu tertentu sampai mengeluarkan cahaya, dan cahaya yang didapat pada waktu itu baru mencapai 3 lumen $/ \mathrm{W}($ Lumen = satuan arus cahaya $)$.
Selanjutnya, tahun 1933 eficacy lampu menjadi \pm 20 lumen dengan menggunakan filamen tungsten atau wolfram yang dibuat membentuk lilitan kumparan. Sistem pembangkitan cahaya buatan ini disebut sistem pemijaran (Incondescence). Namun sebelumnya, tahun 1910 pertama kali digunakan lampu luah (discharage) tegangan tinggi. Prinsip kerja lampu ini menggunakan sistem emisi elektron yang bergerak dari katoda menuju anoda pada tabung lampu yang menumbuk atom-atom media gas yang ada di dalam tabung tersebut. Akibatnya tumbukan akan menjadi pelepasan energi dalam bentuk cahaya. Sistem pembangkitan cahaya ini disebut Luminescence (berpendarnya energi keluar tabung). Mekanisme luah dari lampu tabung Fluorescen dapat dilihat pada Gambar 1.

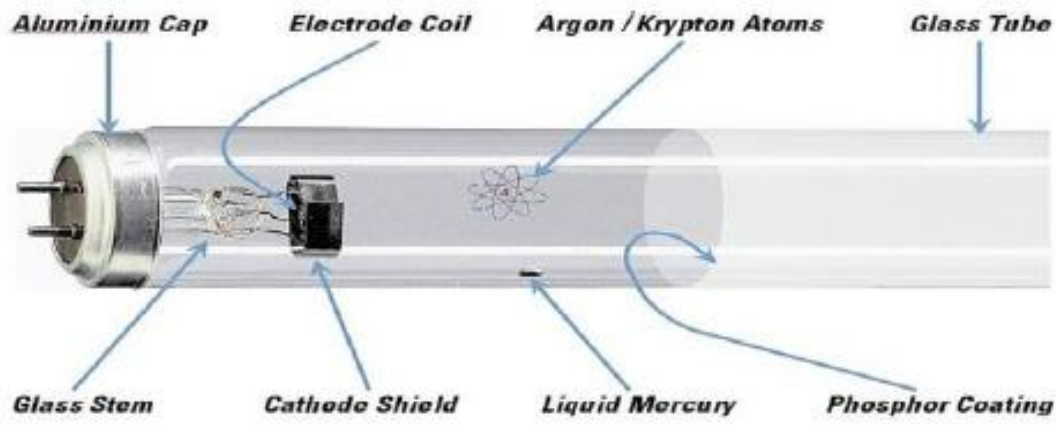

Gambar 1. Mekanisme luah dari lampu tabung Fluorescen

Media gas yang digunakan dapat berbagai macam. Tahun 1932 ditemukan lampu luah dengan gas sodium tekanan rendah dan tahun 1935 dikembangkan lampu luah dengan gas merkuri, kemudian tahun 1939 berhasil dikembangkan lampu fluorescen yang biasa dikenal dengan lampu neon. Selanjutnya lampu xenon tahun 1951, lampu pijar dan gas halogen tahun 1959. Khusus lampu sorot dengan warna yang lebih baik telah dikembangkan gas metalhalide (halogen yang dicampur dengan iodene) pada tahun 1964 sampai pada akhirnya lampu sodium tekanan tinggi tahun 1965 [14]. Prinsip emisi elektron ini dapat meningkatkan efficacy lampu diatas 50 lumen/W, jauh lebih baik /tinggi dibanding dengan prinsip pemijaran. Hal ini jelas karena rugi energi listrik yang diubah menjadi energi cahaya melalui proses emisi elektron dapat dihemat banyak sekali dibanding dengan cara pemijaran dimana energi listrik yang diubah menjadi energi cahaya banyak yang hilang terbuang menjadi energi panas (sebelum menjadi energi cahaya). Gambar 2 memperlihatkan distribusi listrik yang diubah menjadi energi cahaya suatu sumber lampu.

\section{B. Lampu Hemat Energi (LHE)}

\section{Lampu PL dan SL}

Pada era yang terakhir telah dikembangkan lampu pijar dengan sistem induksi magnet yang mempunyai umur paling lama dari lampu-lampu jenis lain \pm 60.000 jam. Namun hal ini masih dalam tahap penelitian dan pengembangan guna mendapat nilai ekonomi yang lebih baik. Untuk sistem penerangan dekade 90 -an yang banyak digunakan oleh masyarakat umum saat ini adalah jenis lampu fluorescen kompak model SL atau PL yang dikenal dengan LHE. Jenis lampu LHE adalah lampu jenis fluorescen atau yang lebih dikenal dengan lampu neon, seperti pada Gambar 3.

Lampu model SL dan PL pada prinsipnya secara teknis sama dengan model lampu jenis fluorescen biasa yaitu efficacy lampu berkisar 60 lumen/W, hanya keistimewaannya mempunyai bentuk yang ringkas, tidak memanjang seperti lampu noen biasa, komponen elektrisnya yang terdiri dari ballast, kapasitor dan stater terpadu dalam suatu kesatuan dalam lampu yang disebut SL. Sedangkan model PL untuk komponen elektrisnya terpisah dari lampu, bentuk kaki lampu dibuat sama seperti pada kaki lampu pijar yaitu dengan sistem ulir dengan ukuran standar E.27.

Lampu fluoresen terdiri dari tabung kaca silinder, dilapisi bagian dalamnya dengan fosfor fluoresen. Setiap tabung fluorescen mengandung merkuri atau amalgam dalam dosis kecil dan campuran gas inert, seperti argon dan kripton atau neon dan argon. Di kedua ujung tabung terdapat elektroda (katoda) yang mengalirkan muatan listrik dari satu ujung ke ujung lainnya, ion yang menarik dalam proses tersebut. Ketika ion-ion ini melewati tabung, mereka bertabrakan dengan partikel-partikel merkuri dan menghasilkan radiasi ultraviolet. Ini pada gilirannya menyebar ke lapisan fosfor yang menghasilkan cahaya putih terlihat. Temperatur warna dan rendering warna dapat ditentukan oleh lapisan campuran fosfor di bagian dalam tabung, Gambar 1. 


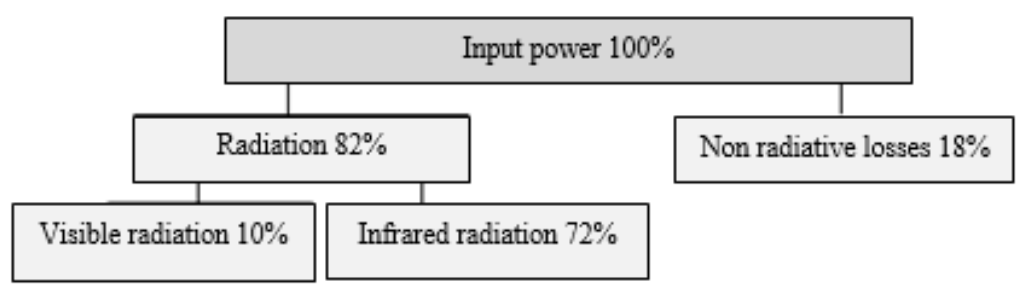

(a) cahaya lampu pijar

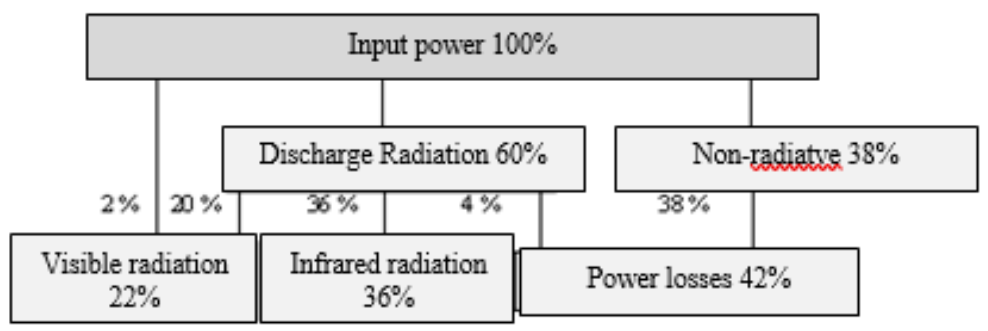

b. Cahaya lampu fluorescen

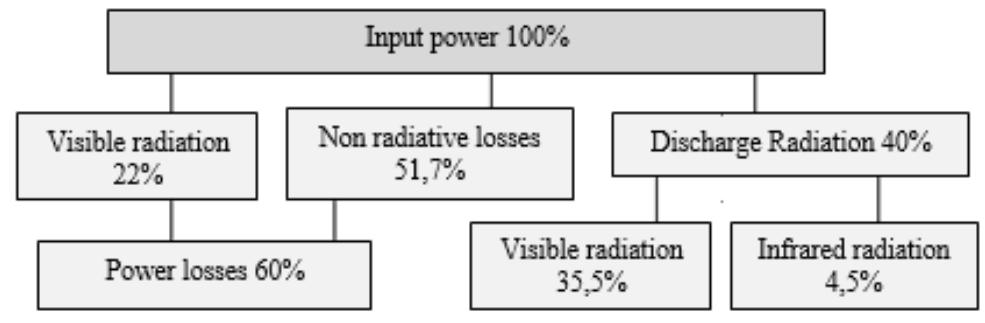

c. Cahaya lampu sodium

Gambar 2. Distribusi listrik yang diubah menjadi energi cahaya suatu sumber cahaya lampu

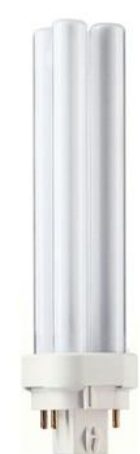

(a) Model PL

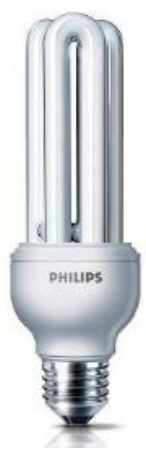

(b) Model SL

Renderasi warna (colour rendering) dapat dipilih berbagai macam sesuai yang diinginkan warna oleh konsumen. Bila diinginkan warna cahaya seperti lampu pijar maka dapat dipilih dengan indeks renderasi warna yang tinggi, karena warna pada lampu pijar adalah warna standar / acuan yang mendekati warna cahaya spektrum yang lengkap seperti pada sinar matahari. Selain itu bila diinginkan warna cahaya lain seperti warna white, cool white, day light, dll, maka hal ini lebih dimungkinkan didapat pada lampu fluorescen dibandingkan dengan lampu pijar yang hanya mempunyai satu jenis redensi warna. Umur lampu fluorescen adalah 8000 jam, lebih lama bila dibandingkan dengan umur lampu pijar yang hanya 1000 jam.

Gambar 3. Lampu fluorescen (LHE)

Tabel I

Renderasi warna dari lampu pijar dan lampu fluorescen

\begin{tabular}{lc}
\hline \multicolumn{1}{c}{ Jenis } & CRT \\
\hline Lampu pijar - Day light & 100 \\
Lampu Fluorescen - Special Warna White TL 40 W / 27 & 93 \\
Lampu Fluorescen - Warna White (Standard) TL 40 W / 29 & 52 \\
Lampu Fluorescen - Special Cool White TL 40 W / 37 & 93 \\
Lampu Fluorescen - Cool Warna White (Standard) TL 40 W / 33 & 65 \\
\hline
\end{tabular}




\section{Compact Fluorescent Lamp (CFL)}

Dalam beberapa tahun terakhir, bola lampu pijar mulai ditinggalkan dan beralih ke lampu sistem fluorescent (FL) yang lebih efisien, lampu fluorescent kompak (CFL), dan sistem pencahayaan light emitting diode (LED). Lampu CFL adalah salah satu inovasi paling sukses di industri dalam hal pencahayaan, yakni lampu CFL modern bertahan 10 kali lebih lama dibanding dengan lampu pijar tradisional. Lampu CFL mengkonsumsi energi yang jauh lebih sedikit dengan menghasilkan jumlah cahaya yang sama. Misalnya, lampu CFL 15 Watt memancarkan jumlah cahaya yang sama dengan bohlam pijar 60 Watt. Terlepas dari keunggulan CFL, mereka memiliki beberapa keterbatasan. Beberapa jenis lampu CFL tidak dapat bekerja dengan baik pada suhu rendah. Selain itu, memungkinkan dapat menghasilkan interferensi frekuensi radio (RFI), tidak tahan terhadap guncangan, dan memiliki merkuri di dalam tutup kacanya [15].

\section{Ballast Elektronik (BE)}

Ballast jenis ini mempunyai keunikan khusus, yaitu sistem bekerjanya tidak lagi menggunakan gulungan (kumparan) kawat pada suatu inti besi, tetapi telah diganti dengan sistem rangkaian elektronik sehingga besarnya rugi-rugi pada inti besi pada kumparan menjadi tidak ada lagi, dan hanya sedikit rugi saja karena adanya rangkaian atau sirkit. Inilah yang paling menguntungkan dalam penghematan energi listrik yang diserapnya. Keuntungan lain yang didapat adalah dapat diatur komsumsi arus listriknya dengan tetap mempertahanakan besar tegangan yang diinginkan, sehingga ballast elektronik dapat digunakan untuk sistem pengaturan energi listrik sesuai yang dibutuhkan pada suatu ruangan.

Bila dibandingkan dengan BK, maka BE mensuplai bagian elektronik dari lampu fluorescen dengan tegangan frekuensi tinggi (frekuensi pelayanan $39 \mathrm{~Hz}$ ) sehingga menaikkan tingkat penerangan cahaya dari lampu dan jelas menurunkan pemakaian energi. Selain itu hanya sedikit energi diubah menjadi rugi daya dan memperpanjang rentang hidup (umur pakai lampu-lampu fluorescen). Dengan sistem sirkuit elektronik, maka ballast menjadi lebih ringan dan lebih kecil dibandingkan dengan BK (sistem gulungan kawat), seperti yang terlihat perbandingannya dalam Tabel II.

Tabel II

Perbandingan Ballast Elektronik (BE) dengan Ballast Konvensional (BK) [16]

\begin{tabular}{|c|c|c|c|}
\hline No. & Uraian & $\mathrm{BE}$ & BK \\
\hline 1. & $\begin{array}{l}\text { Rugi daya listrik pada } \\
\text { TL } 40 \mathrm{~W}\end{array}$ & $0,5 \mathrm{~W}$ & $8 \mathrm{~W}$ \\
\hline 2. & $\begin{array}{c}\text { Faktor daya listrik (Cos } \\
\varphi)\end{array}$ & 1 & $\begin{array}{l}<1 \text { (Dapat diperbaiki dengan } \\
\text { memasang kapasitor) }\end{array}$ \\
\hline 3. & Berat dan volume & Ringan dan kecil & Berat dan besar \\
\hline 4. & Umur pakai & 13 Tahun & 5 Tahun \\
\hline 5. & Pengaruh kedip & Tidak ada & Ada \\
\hline 6. & $\begin{array}{l}\text { Pengaruh terhadap } \\
\text { umur pakai lampu }\end{array}$ & Lebih lama & - \\
\hline 7. & Bunyi dengung & Tidak ada & Kadang-kadang \\
\hline 8. & Harga & Mahal & Murah \\
\hline 9. & Penggunaan Energi & $\begin{array}{c}\text { Dapat menghemat daya kurang lebih } \\
50 \% \text { dari Ballast biasa }\end{array}$ & Komsumsi daya yang besar \\
\hline 10. & $\overline{\text { Starting }}$ & Starting penyalaan kurang dari 1 detik & Starting penyalaan 7,5 detik \\
\hline 11. & Kedip Tegangan & $\begin{array}{l}\text { Tidak dipengaruhi adanya kedipan } \\
\text { (cahaya tidak berkedip) }\end{array}$ & $\begin{array}{l}\text { Sangat dipengaruhi oleh kedipan } \\
\text { PLN }\end{array}$ \\
\hline 12. & Sistem operasi & $\begin{array}{l}\text { Dapat beroperasi pada tegangan 100- } \\
\qquad 240 \mathrm{~V}\end{array}$ & $\begin{array}{l}\text { Operasi kerja ballast lebih besar } \\
\text { dari } 210 \mathrm{~V} \text {, sehingga bila terjadi } \\
\text { Lower Voltage Ballast tidak dapat } \\
\text { bekerja, lampu tidak dapat menyala }\end{array}$ \\
\hline 13. & Life Time & $\begin{array}{l}\text { Life Time yang relatif lama terhadap } \\
\text { lampu TL-nya. }\end{array}$ & $\begin{array}{l}\text { Life Time yang relatif singkat } \\
\text { terhadap lampu TL-nya. }\end{array}$ \\
\hline 14. & Starter & Tidak membutuhkan starter & $\begin{array}{lr}\text { Dalam } & \text { pengoperasiannya } \\
\text { membutuhkan perangsang (starter). }\end{array}$ \\
\hline 15. & Faktor Kerja & Power faktor yang tinggi lebih dari 0,9 & $\begin{array}{l}\text { Power Factor relatif rendah, kurang } \\
\text { lebih } 0,4 \text {. }\end{array}$ \\
\hline
\end{tabular}

Penggunaan BE, disamping mempunyai power faktor yang tinggi dan dapat menghemat biaya listrik juga menguntungkan PLN, antara lain:

1. Memperkecil/menghilangkan power loss (VAR) yang relatif tinggi.
2. Menghemat total power (VA) sehingga dapat dikontasikan kepada konsumen baru.

3. Dapat menambah kapasitas daya di jaringan sistem distribusi. 
4. Meringankan power out distribusi transformator arus yang berkurang, sehingga dapat menghemat / memperpanjang life time transformator.

\section{METODE PENELITIAN}

Metode yang digunakan dalam penelitian ini digunakan kajian pustaka dan eksperimental melalui pengukuran arus dan tegangan pada sampel lampu yang digunakan. Untuk dapat merealisasikan suatu sistem penerangan dengan pemakaian energi yang lebih efisien, maka dalam penelitian ini yang dibagi dalam 3 tingkat, yang diterapkan untuk penerangan: perkantoran, pabrik, perkantoran [17]. Dalam sistem penerangan ini tak hanya dikemukakan suatu teori dengan visi kemudian hari, tapi program tersebut juga dapat direalisasikan dengan sarana yang tersedia sekarang.

- Pada tingkat I: Sistem perlampuan (instalasi lampulampu yang telah terpasang) yang lama diganti dengan sistem perlampuan yang lebih efisien pemakaian energinya, misalnya lampu-lampu yang mempunyai tutup plastik putih dari $18,3 \mathrm{~W} / \mathrm{m}^{2}$, yang dapat menghemat kira-kira $43 \%$ dan sering dipasang di pabrik dengan hall atau ruang kerja yang luas.

- Pada tingkat II diusahakan untuk dapat tercapai suatu unjuk kerja perlampuan yang ekonomis, maka ballast elektronik (BE) disini memberi solusi yang tepat. Suatu inovasi teknik perlampuan dalam dekade terakhir yang menghasilkan suatu potensial hemat energi sampai $25 \%$.

- Pada tingkat terakhir (III) diusulkan supaya cahaya matahari dalam ruang dimanfaatkan secara terarah, artinya dengan perantara alat pengatur yang bergantung pada cahaya matahari dan mengontrol penerangan lampu-lampu (artificial illumination), dapat menurunkan lagi pemakaian energi sebesar $25 \%$.

\section{HASIL DAN PEMBAHASAN}

\section{A. Analisis Ekonomis}

Analisis secara ekonomi perbandingan antara lampu hemat energi dengan lampu biasa (pijar) sebagai berikut:

- Jika konsumen menggunakan lampu hemat energi 20 $W$ dimana umur dari lampu ini $=10.000$ jam akan sama cahayanya jika menggunakan lampu pijar 100 W sedangkan umur dari lampu pijar ini hanya 1000 jam. Dengan demikian 1 lampu hemat energi yang dayanya hanya $20 \mathrm{~W}$ akan setara dengan 10 buah lampu pijar yang dayanya $100 \mathrm{~W}=1000 \mathrm{~W}$ ".

Untuk lebih jelasnya dapat dilihat dalam Gambar 4, sedangkan Tabel III memperlihatkan perbandingan lampu hemat energi dan lampu biasa [18].

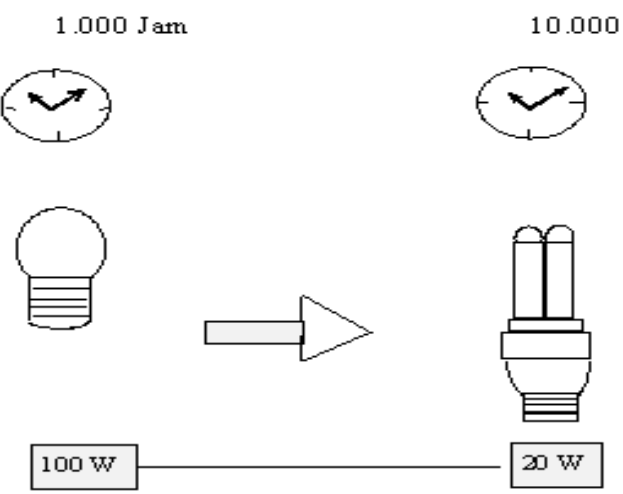

Gambar 4 Perbandingan lampu hemat energi dan lampu biasa

Tabel III

Data perbandingan lampu hemat energi dengan lampu pijar

\begin{tabular}{|c|c|c|c|c|c|}
\hline \multicolumn{4}{|c|}{ Lampu Hemat Energi } & \multicolumn{3}{|c|}{ Lampu Biasa (TL \& Pijar(*)) } \\
\hline $\begin{array}{c}\text { Brigthness } \\
\text { (Watt) }\end{array}$ & $\begin{array}{c}\text { Umur } \\
\text { (jam) }\end{array}$ & $\begin{array}{c}\text { Harga } \\
(\mathrm{Rp})\end{array}$ & $\begin{array}{c}\text { Brigthness } \\
\text { (Watt) }\end{array}$ & $\begin{array}{c}\text { Umur } \\
(\mathrm{Jam})\end{array}$ & $\begin{array}{c}\text { Harga } \\
(\mathrm{Rp})\end{array}$ \\
\hline 5 & 5.000 & 31.500 & 25 & 1000 & $3.500(*)$ \\
9 & 6.000 & 31.500 & 40 & 1000 & 21.000 \\
11 & 6.000 & 31.500 & 55 & 1000 & 24.500 \\
13 & 7.500 & 32.000 & 65 & 1000 & \\
15 & 7.500 & 32.000 & 75 & 1000 & $4.500\left(^{*}\right)$ \\
16 & 9.000 & 39.000 & 80 & 1000 & $4.500(*)$ \\
18 & 9.000 & 39.000 & 90 & 1000 & \\
20 & 10.000 & 40.000 & 100 & 1000 & $7.500(*)$ \\
26 & 10.000 & 42.000 & 130 & 1000 & \\
\hline
\end{tabular}

Selanjutnya, Tabel IV memperlihatkan analisis penggantian lampu TL dan lampu tipe CFL dengan lampu LED. Berdasarkan tabel ini, secara ekonomis terlihat bahwa ada penghematan komsumsi energi dari 1.057 Watt menjadi 619 Watt. Artinya terdapat penghematan energi sekitar 438 Watt atau pengurangan tagihan listrik setiap bulan. Penggantian lampu ini berdasarkan atas kesetaraan atau kesamaan iluminasi/pencahayaan dari spesifikasi lampu yang terpasang dengan alternatif lampu pengganti.

Tabel IV Analisis Ekonomis Penggantian Lampu

\begin{tabular}{|c|c|r|c|r|}
\hline $\begin{array}{c}\text { Jenis } \\
\text { Lampu } \\
\text { yang } \\
\text { terpasang }\end{array}$ & $\begin{array}{c}\text { Jumlah } \\
\text { (buah) }\end{array}$ & $\begin{array}{c}\text { Daya } \\
\text { (Watt) }\end{array}$ & $\begin{array}{c}\text { Alternatif } \\
\text { penggantian } \\
\text { lampu }\end{array}$ & $\begin{array}{c}\text { Daya } \\
\text { (Watt) }\end{array}$ \\
\hline TL 36 W & 10 & 360 & LED 20 W & 200 \\
\hline CFL 14 W & 5 & 70 & LED 9 W & 45 \\
\hline CFL 13 W & 15 & 195 & LED 8 W & 120 \\
\hline CFL 36 W & 7 & 252 & LED 22 W & 154 \\
\hline TL 18 W & 10 & 180 & LED 10 W & 100 \\
\hline Jumlah & & 1.057 & & 619 \\
\hline
\end{tabular}

\section{B. Analisis Biaya}

Apabila menggunakan lampu hemat energi 20 Watt dengan harga Rp 40.000 dipakai selama 10.000 jam. Biaya operasional dari lampu tersebut sesuai dengan ketentuan dari PLN 1 KWH (Kilo Watt Jam) atau Besarnya daya yang terpakai $(\mathrm{kW}) \mathrm{x}$ Lama waktu dipergunakan $(\mathrm{Jam})=\mathrm{Rp}$ 169/kwh untuk daya 0-450 VA. Jadi biaya operasional selama 10.000 jam $=(0,002 \mathrm{x}$ $10.000) \times \operatorname{Rp} 169,-=\operatorname{Rp} 3.380$. Dengan demikian biaya 
total = biaya awal + biaya operasional $=\mathrm{Rp} 40.000+$ Rp3.380 = Rp 43.380.

Berdasarkan Tabel III terlihat bahwa lampu yang sepadan/setara dari lampu hemat energi adalah lampu 100 Watt dengan umur pemakaian 1000 jam. Artinya perbandingannya $=1: 10$. Dengan demikian jika dihitung biaya awal selama pemakaiannya 10.000 jam (10 buah lampu yang dipakai) dengan harga 1 buah lampu = Rp7.500 × $10=75.000,-$. Sedangkan biaya operasional selama 10.000 jam dengan daya $100 \mathrm{Watt}=10.000$ jam $\mathrm{x}$ $0,1 \mathrm{Kw}=1000 \mathrm{KWH} \times \mathrm{Rp} 169,-=\mathrm{Rp} 169.000,-$. Jadi biaya total penggunaan lampu biasa $(\mathrm{TL})=$ Biaya awal + Biaya operasional $=\operatorname{Rp} 75.000+\operatorname{Rp} 169.000=\operatorname{Rp} 244.000$. Jadi penghematan yang diperoleh $=$ Rp244.000- Rp43.380 = Rp200.380,-(Seratus empat belas ribu tiga ratus delapan puluh ribu rupiah) [17].

\section{Analisis Perbandingan Ballast Elektronik dengan Ballast Induktif}

Meningkatnya perkembangan teknologi banyak menyerap energi dan amat dikwatirkan timbulnya krisis energi berkala. Oleh karena itu muncul himbauan pemerintah tentang pemanfaatan sumber daya alami untuk dapat digunakan sehemat mungkin atau sesuai kebutuhan. Hal tersebut berkaitan erat dengan kelistrikan karena listrik adalah salah satu faktor penyerap energi energi yang tidak sedikit. Selain itu, listrik termasuk kebutuhan primer sehari-hari, sehingga penggunaannya harus dapat ditekan agar tidak terjadi pemborosan energi. Sebagai contoh: adalah penggunaan BK yang banyak di kalangan masyarakat untuk daerah perumahan dan perkantoran. BK mempunyai rugi-rugi daya (Power Loss) yang tinggi, sehingga dapat merugikan konsumen dan juga Perusahaan Listrik Negara (PLN).

Sasaran utama pemanfaatan BE adalah membantu program pemerintah dalam menanggulangi kisis energi. Dengan banyaknya konsumen yang menggunakan BE baik Instansi Pemerintah maupun Gedung Perkantoran Negeri/Swasta akan dapat menghemat sumber energi, sehingga kita dapat memanfaatkan sumber energi dengan efisien.

\section{Perbandingan Arus}

Power supply PLN $220 \mathrm{~V}$ Cos $\phi$ sumber $=0,8$, melayani lampu TL 1 x 40 Watt. Bila menggunakan BI $\cos \phi=0,4$, maka diperoleh arus yang mengalir pada lampu sebagai berikut:

$$
\begin{aligned}
\mathrm{I} & =\mathrm{W} / \mathrm{a} \cdot \mathrm{V} \cdot \operatorname{Cos} \phi \mathrm{S} \times \operatorname{Cos} \phi \mathrm{BI} \\
& =40 / \sqrt{2} \times 220 \times 0,8 \times 0,4=0,401 \text { Ampere }
\end{aligned}
$$

Selanjutnya dengan menggunakan $\mathrm{BE} \operatorname{Cos} \phi: 0,9$, maka diperoleh:

$$
\begin{aligned}
\mathrm{I} & =\mathrm{W} / \mathrm{a} \cdot \mathrm{V} \cdot \operatorname{Cos} \phi_{\mathrm{s}} \times \operatorname{Cos} \phi \mathrm{B} \\
& =40 / \sqrt{ } 2 \times 220 \times 0,8 \times 0,9 \\
& =0,178 \text { Ampere }
\end{aligned}
$$

Dengan demikian penggunaan BE dapat menghemat arus sebesar:

0,233 Ampere

$$
\text { Induktif - Elektronik }=0,401 \mathrm{~A}-0,178 \mathrm{~A}=
$$

$$
\text { atau }(\%)=0,223 / 0,401 \times 100 \%=55,61 \% \text {. }
$$

\section{Pembahasan}

Hemat energi adalah suatu tema yang menarik dan perhatian penuh di seluruh masyarakat umum, akan tetapi dalam hubungan ini jarang dipikirkan ke masalah penerangan. Ternyata di Jerman, $10 \%$ dari seluruh kebutuhan energi $480.000 \mathrm{GWH}\left(1 \mathrm{GWH}=1 \times 10^{6} \mathrm{KWH}\right)$ dipakai tujuan penerangan yang dibagi lagi dalam $20 \%$ untuk rumah pribadi dan $80 \%$ untuk industri, perdagangan, penerangan umum dan sebagainya. Dalam sektor kawasan industri selain lampu sodium tekanan tinggi, banyak juga dipasang lampu-lampu jenis fluorescen sejumlah kira-kira 310 juta buah. Artinya ada trend di Eropa bahwa pemakaian atau kebutuhan terhadap lampu-lampu penerangan tersebut akan terus meningkat.

Contoh kasus di pelabuhan udara Frankrurt Jerman menerapkan hemat energi di instalasi perlampuan dan $10 \%$ dari seluruh daya listrik tersebut dibutuhkan untuk penerangan. Kemudian telah terpasang 300.000 buah lampu fluorescen dan 25.000 buah lampu jenis halogen. Selama 10 tahun telah dipasang 50.000 buah BE yang menghasilkan hemat energi antara $23 \%$ dan $37 \%$, sehingga biaya investasi yang tinggi dapat dilunasi dalam periode 1 dan 2 tahun. Selain itu rentang hidup (umur pakai) dari lampu-lampu yang dilengkapi dengan BE dalam operasi terus-menerus (nyala) dapat dinaikkan dari kira-kira 3.500 jam menjadi 24.000 jam.

Dalam penilaiannya harus dibedakan antara aspekaspek ekologis, ekonomis dan ergonomis. Sistem penerangan ekonomis yang tinggi dapat dicapai dengan cara penghematan biaya-biaya energi, ongkos-ongkos pelayanan, harga lampu yang rendah, jaminan yang maksimun terhadap kebakaran dan tempat kerja maupun persyaratan kerja yang baik. Menurut [18], bahwa dengan memakai lampu hemat energi dan memperpanjang rentang hidup dari perlampuan, maka dapat menghemat atau mengurangi pemakaian sumber-sumber energi. Ergonomi akan membuat daya penglihatan yang tinggi, tak ada gangguan kebisingan, penerangan untuk tiap-taip manusia dan kesejahteraan masyarakat.

Adanya penghematan energi sistem penerangan aka memberi dampak yang sangat nyata. Sebagai contoh, di negara Jerman ballast konvensional dari sejumlah kirakira 310 juta lampu fluorescen yang terpasang, diganti dengan ballast elektronik, maka setiap tahun dapat menghemat kira-kira $6500 \mathrm{GWH}$ energi listrik, yang dapat disamakan dengan pemakaian 2 juta ton batubara pertahun di dalam pembangkit listrik konvensional.

Selanjutnya, dibandingkan dengan lampu pijar dengan jumlah cahaya / iluminasi yang sama, lampu CFL menggunakan daya listrik seperlima hingga sepertiga, dan bertahan delapan hingga lima belas kali lebih lama. Jenis lampu CFL mempunyai harga pembelian yang lebih tinggi dibanding lampu pijar, tetapi dapat menghemat lebih dari lima kali harga pembelian dalam biaya listrik selama masa pakai lampu. Kemudian, dengan penggantian dari lampu CFL ke lampu LED akan memberikan penghematan yang lebih tinggi lagi dengan jumlah iluminasi yang sama. Oleh karena itu, penggunaan lampu LED akan memberikan dampak penghematan energi listrik, walaupun biaya awalnya cukup tinggi. 


\section{KESIMPULAN}

Berdasarakan hasil pembahasan, maka dapat disimpulkan sebagai berikut:

1. Penggunaan lampu hemat energi membutuhkan biaya awal yang lebih mahal dibanding dengan lampu biasa, namun dalam pengoperasian sehari-hari menjadi lebih ekonomis sehingga diperoleh penghematan energi antara $20 \%-80 \%$.

2. Dengan adanya pola penggantian dari lampu biasa menjadi lampu hemat energi, maka akan membantu PLN mengurangi daya reaktif sehingga akan mengurangi rugi-rugi daya yang terjadi pada jaringan listrik.

3. Dengan adanya perubahan penggantian ballast konvensional menjadi ballast elektronik akan meningkatkan faktor daya listrik sebesar 55,61\%.

\section{REKOMENDASI}

- Dalam hal penghematan energi, jika satu orang tiap harinya mematikan lampu $25 \mathrm{~W}$, maka akan didapat penghematan energi di seluruh Indonesia yang telah menggunakan listrik \pm 100 juta penduduk adalah $=$ 2.500 juta Watt sama dengan 2.500 MW.

- Jika setiap orang menggunakan lampu hemat energi $20 \mathrm{~W}$ dimana umur dari lampu ini $=10.000$ jam akan sama cahayanya jika menggunakan lampu pijar 100 $\mathrm{W}$, sedangkan umur dari lampu pijar ini hanya 1000 jam.

- Dengan demikian 1 lampu hemat energi yang dayanya hanya $20 \mathrm{~W}$ akan setara dengan 10 buah lampu pijar yang dayanya $100 \mathrm{~W}=1000 \mathrm{~W}$.

\section{UCAPAN TERIMA KASIH}

Ucapan terima kasih Ketua LPPM Undana yang telah menfasilitasi penelitian, DIKTI, dan Kepala Laboratorium Teknik Elektro yang membantu terlaksananya penelitian ini.

\section{REFERENSI}

[1] Anonim. Statistik PLN. PT. PLN (Persero). Jakarta. 1998.

[2] Ribarich, Thomas J. Ribarich, John J. A New Procedure for High-Frequency Electronic Ballast Design, IEEE Industry Applications Society Annual Meetings, New Orleans, Louisiana, Oct. 1997.

[3] Costa, Marco Antonio Dalla, Alvarez, Jose Marcos Alonso, Garcia, Jorge, Kirsten, Andre Luis, Vaquero, David Gacio, Microcontroller Based High-Power-Factor Electronic Ballast to Supply Metal Halide Lamps, IEEE Transactions On Industrial Electronics, vol.59, no.4, April 2012.
[4] A. Haque, Rahul Sharma, Design of Optimum Controller for electronic control system of Metal Halide High Intensity Discharge lamps, IEEE student congress of Engineering System, pp. 1-6, 2014.

[5] A. Haque, Ballast with circuit for detecting and eliminating an arc condition, US Patent, 7183721, 2007.

[6] Diaz, F.J. Azcondo, F.J. Casanueva, R. Branas, C. Microcontroller Software Applied to Electronic Ballast Design, Power Electronics and Applications, EPE '09. 13th European Conference on, Barcelona, Spain, Sept. 2009.

[7] A Haque, Evaluation of Operational Characteristics of Electronics Ballast for Metal Halide HID Lamps, IEEE Internationa Conference Power Electronics, Drives and Energy Systems, pp. 1 -7, 2006.

[8] Cosby, M.C., Jr., Nelms, R.M., "A Resonant Inverter for Electronic Ballast Applications, IEEE Transactions on Industrial Electronics, vol.41, no.4, Aug. 1994.

[9] Rahul Sharma, Ahteshamul Haque, Simulation and analysis of Power Factor correction in Electric control system for Metal Halide High Intensity Discharge Lamp, International conference on Advances in Electronics and Electric Engineering, pp. 185-192, Vol. 4, 2014.

[10] Qinghong Yu; Radzinski, C., Dernovsek, J., Adaptive Preheat and Strike of Microcontroller based Ballast, IEEE Industry Applications Conference, Oct. 2004.

[11] Alonso, J.M., Villegas, P.J., Diaz, J., Blanco, C., Rico, M., A Microcontroller-based Emergency Ballast for Fluorescent Lamps, IEEE Transactions on Industrial Electronics, vol.44, no. 2, Aug. 2002.

[12] Moo, C.S., Chen, W.M., Yen, H.C., A Series-Resonant Electronic Ballast for Rapid-Start Fluorescent Lamps with Programmable Starting, Proceedings of the Power Conversion Conference, vol.1, 2002, PCC-Osaka 2002.

[13] Debanka De, Sangita Sahana, and Biswanath Roy. Performance analysis of fluorescent and led lamp system. Conference Paper: ICCECE. December .2016.

[14] Anonim. Lampu Fluorescen. Majalah Elektro Indonesia, Nomor 1, Bandung, 1994.

[15] Lee AHW. Verification of electricity savings for lighting using short-term and long-term monitoring. Energy Conversion and Management. 41 (18), pp. 19992008, 2000.

[16] Anonim. Ballast Elektronik dan Ballast Konvensional. Majalah Elektro Indonesia No. 11 Th. III, Juni/Juli, 1996.

[17] Sudirman dan Sri Kurniati. Studi Penggunaan Lampu Hemat Energi Pada Sektor Penerangan. Laporan Penelitian Dosen Muda, Lembaga penelitian, Undana, Kupang, 1999.

[18] Sudirman dan Sri Kurniati. Analisis Penggunaan Lampu Hemat Energi dan Ballast Elektronik Di Kelurahan Oesapa Kecamatan Kelapa Lima Kotamadya Kupang. Laporan Penelitian Dosen Muda Lembaga Pengabdian Pada Masyarakat Universitas Nusa Cendana, Kupang, 2000. 